\title{
Steroid use and its adverse effects: a review
}

Kleiverson de Oliveira Silva ${ }^{1^{*}}$; Alicya Beatriz de Santana Pereira ${ }^{2}$; Paulo César Barbosa de Brito Filhos; Joana Bulhões Alvares da Silva $^{4}$; José Ricardo de França Silva ${ }^{5}$; Cláudio Junyo dos Santos ${ }^{6}$; Noályta Maelly da Silva ${ }^{7}$; Vitória Lanuza Cavalcanti de Lima e Silva ${ }^{8}$; Marcelo Francisco Galdino da Silva"; Elionay Gomes dos Santos Silva ${ }^{10}$; Tatiana Jaqueline Moreira dos Santos Mota ${ }^{11}$; Luana Carla dos Santos ${ }^{12}$; Danyel Gomes Teixeira de Freitas ${ }^{13}$; Joaci Paulo da Mota Júnior ${ }^{14}$; Danilo Augusto Ferreira Fontes ${ }^{15}$

1 Pharmacist at University Center of Vitória de Santo Antão - UNIVISA, Postgraduate in clinical pharmacy and postgraduate hospital pharmacy at Novo Horizonte College.

2 Nutritionist at University Center of Vitória de Santo Antão - UNIVISA.

3 Undergraduate of the bachelor's degree in nutrition at Federal University of Pernambuco - UFPE.

4 Undergraduate of the bachelor's degree in pharmacy at the University Center of Vitória de Santo Antão - UNIVISA.

5 Undergraduate of the bachelor's degree in pharmacy at University Center of Vitória de Santo Antão - UNIVISA.

6 Undergraduate graduated from the bachelor's degree in pharmacy at University Center of Vitória de Santo Antão - UNIVISA.

7 Undergraduate of the bachelor's degree in pharmacy at University Center of Vitória de Santo Antão - UNIVISA.

8 Undergraduate nursing degree at University Center of Vitória de Santo Antão - UNIVISA.

9 Undergraduate graduated from the bachelor's degree in pharmacy at University Center of Vitória de Santo Antão - UNIVISA.

10 Undergraduate of the bachelor's degree in nutrition at Federal University of Pernambuco - UFPE.

11 Undergraduate of the bachelor's degree in pharmacy at University Center of Vitória de Santo Antão - UNIVISA.

12 Undergraduate of the bachelor's degree in pharmacy at University Center of Vitória de Santo Antão - UNIVISA.

13 Graduating in Biomedicine fat Faculty of Technology and Sciences of Northern Paraná - UNIFATECIE.

14 Undergraduate of the bachelor's degree in Physical Education course at Federal University of Pernambuco - CAV/UFPE

$15 \mathrm{PhD}$ in pharmaceutical sciences at Federal University of Pernambuco - UFPE. Coordinator of the pharmacy course of the university center of Vitória de Santo Antão - UNIVISA.

E-mail adresses: : kleiversonsilva1994@gmail.com (Kleiverson de Oliveira Silva), biiaalicya@gmail.com (Alicya Beatriz de Santana Pereira), thepaulobrito@gmail.com (Paulo César Barbosa de Brito Filho), joanafarmacia2018@gmail.com (Joana Bulhões Alvares da Silva), ricardo_franca1@hotmail.com (José Ricardo de França Silva), claudiojunyodossantos@gmail.com (Cláudio Junyo dos Santos), noalytamaelly@gmail.com (Noályta Maelly da Silva), vitoria_lanuza@outlook.com (Vitória Lanuza Cavalcanti de Lima e Silva), marcelo.fgs85@gmail.com (Marcelo Francisco Galdino da Silva), elionayg44@gmail.com (Elionay Gomes dos Santos Silva), tatiamoreiramota@outlook.com (Tatiana Jaqueline Moreira dos Santos Mota), luanacarla26@hotmail.com (Luana Carla dos Santos), vmais019@gmail.com (Danyel Gomes Teixeira de Freitas),j.jr.mota@hotmail.com (Joaci Paulo da Mota Júnior), ddanilofontes@gmail.com (Danilo Augusto Ferreira Fontes).

${ }^{*}$ Corresponding author

\section{To cite this article:}

Silva, K.O.; Pereira, A.B.S.; Filho, P.C.B.B.; Silva, J.B.A.; Silva, J.R.F.; Santos, C.J.; Silva, N.M.; Lima e Silva, L.L.C.; Silva, M.F.G.; Silva, E.G.S.; Mota, T.J.M.S.; Santos, L.C.; Freitas, D.G.T.; Júnior, J.P.M.; Fontes, D.A.F. Steroid use and its adverse effects: a review. International Journal of Sciences. Vol. 2, No. 3, 2021, pp. 31-36. ISSN 2763-5392.

Received: 10 09, 2021; Accepted: 10 10, 2021; Published: 11 03, 2021

\begin{abstract}
Still scarce the theme of steroid hormones, anabolic androgenic and derived from testosterone, are tasked with a succession of organic consequences, which can be gathered into anabolic and androgenic. Anabolic effects stimulate the growth of mass, muscle strength and protein synthesis, while androgenic effects lead to the development of manly aspects. These steroid hormones, because they have lipid status, easily surpass the cell membrane until it reaches the DNA nucleus, producing high expression of the genes charged for the synthesis of actin and myosin. The exacerbated use in the consumption of these substances is growing surprisingly among young people and adults, who make use simply with the aim of improving the physical appearance.
\end{abstract}


2 Silva, K.O.; Pereira, A.B.S.; Filho, P.C.B.B.; Silva, J.B.A.; Silva, J.R.F.; Santos, C.J.; Silva, N.M.; Lima e Silva, L.L.C.; Silva, M.F.G.; Silva, E.G.S.; Mota, T.J.M.S.; Santos, L.C.; Freitas, D.G.T.; Júnior, J.P.M.; Fontes, D.A.F. Steroid use and its adverse effects: a review...

Where this hormone can cause long- or short-term problems, from continued doses, steroids can lead to complications in healthy people. They can also cause several side effects from prostate cancer, coronary heart disease, liver cancer, and several others.

Keywords: Hormones. Anabolic steroids. Consumption.

\section{Introduction}

Over time we come across several cases of search for the body that desires with this the aesthetic needs of today's society, makes the population invest more and more time, energy and financial resources in the consumption of goods and services destined to the construction of a perfect body. The obsessive search for the ideal body has become a problem due to the indiscriminate use of anabolic steroids, because users are unaware of the harm caused by their indiscriminate use putting their own lives at risk, and may develop, cancer, anomalies in muscles, caused by these anabolic steroids, and may even lead to a depression, among other causes (FELICIO, 2010).

Practitioners and athletes of physical activity, wish to test frequently, any substance to improve their performance in the sport. The genic ergo aids used by athletes are encouraged by the search for millionaire sponsorships, fame and power. (FELICIO, 2010).

Anabolic steroids, which are anabolic androgen steroids, are synthetic or artificial hormones, which cause a kind of 'imitation" of the hormone testosterone. In addition to having the knowledge of a male hormone, testosterone is also found in women's, in much smaller amount (OVIEDO, 2013).

Anabolic have two effects, the anabolic effect, which influences in the case of muscle growth, lipid control, strength, among other effects; the androgen effect has a certain influence on male characteristics such as voice change, sexual organ growth, mustache growth, beard; hair growth in the armpits and genital areas, and a certain feeling of aggressiveness; There are several cases of women who use this type of anabolic with testosterone present, and it is reported several of these cases cited, such as voice change (OVIEDO, 2013).

Steroid hormones are of lipid origin, formed from cholesterol being synthesized only by organs such as gonads, ovaries and adrenal glands, located in the kidney. And they are responsible for the harmony of the primordial functions in the body. In addition to steroids, insulin, glucagon and thyroid hormones, among others. Steroids are grouped into 3 (three) basic categories (OVIEDO, 2013).

However, anabolic steroids are directed to the use of therapeutic form, used in the treatment of diseases such as rickets, but, most adherents, use with the aim of having a gain in training capacity (decreased tiredness), in this will occur the increase in physical strength and muscle mass. Among professional athletes, the use of this substance characterizes doping. The use of these drugs is higher among men, but the rate of women using anabolic steroids is increasing. (DANTAS, 2011)

Increased heart muscle can lead to heart attacks, and may also cause headaches and dizziness. In the liver, cases of tumors, cirrhosis have already been detected. There is the incidence of jaundice and liver function problems. In the kidneys and urinary system, there is an increase in water absorption. The kidneys are high and, in the future, tumors, burning and pain may appear when urinating (MUNIZ et al., 1997).

Problems occur in bone growth and development when EEAs (Anabolic Androgenic Steroids) are used by adolescents. In the pubertal phase, these substances cause the acceleration of the closure of epiphyses (regions of the bones responsible for growth), reducing the growth time, and thus resulting in a smaller stature of the individual. These hormones should not be consumed during pregnancy, since they reach the placental barrier and masculinize the fetus (DE FARIA, 2015).

According to the medical researchers Parkinson $\mathrm{AB}$ and Evans NA, in the article "Anabolic androgenic steroids: a survey of 500 users" published in Med Sci Sports Exerc 2006: we observed information of the following side effects: testicular atrophy (63.6\%); acne (63.4\%); insomnia (51.2\%); stretch marks (44.4\%); mood change (42.8\%); sexual dysfunction $(24.6 \%)$; gynecomastia $(23 \%)$, based on these studies, it is observed that among the interviewees, there is a majority in the cause of testicular atrophy, which and an anabolic androgen effect, then we observe acne, which are rashes and can be found the face and part of the chest and back, thus leaving oily the face, among other causes mentioned above (PARKINSON; EVANS, 2006)

In this context, the objective of this work is to present the risks that anabolic androgenic steroids can cause to the body if misused.

\section{Methodology}

The study was characterized through a bibliographical research. For the bibliographic survey, the collection of UNIVISA's library and sites such as Bireme, PubMed, Lilacs and SciELO were used, in addition to online information platforms. This study was a review study of integrative literature, where information on adverse and therapeutic effects, history and the discovery of The EEAs (Anabolic Androgenic Steroids) were collected.

The publications used were between 2015 and 2018. To survey the articles, we used the descriptor "steroids" combined with the term "anabolic", "side effects" and "history and discovery", used for the sample. The methods used for the selection of materials were: articles that raised the subject, written in Portuguese, exposed, among times indexed in lilacs and SciELO databases.

\section{Results and Discussion}




\subsection{Anabolic steroids and their Historical Context}

Since antiquity, the need to be greater than the best, and thus guarantee a status of respect within daily life, made man value in an extreme way the cult of physical beauty and body size. Whoever achieved the standard, dictated by society, would be observed as an example of vigor, power, beauty and sexuality. (FREEDMAN, 2009)

Such attributes began to be acquired from the sexual organs even before the word 'hormone' was known. There is chaos that in literature that indicate that ancient peoples, believers in the culture that there was some harmony between the sexual organs of animals and some strong substance and would bring pleasures, fed on some organs and their secretions to thus in the future produce greater courage and increase their strength and sexual function (PHILIPPI, 2004).

The excessive search for means that improve physical performance is much older than is known. In Rome, the gladiators of the Colosseum used natural stimulants as a weapon for force in their combat, while the Greeks used hallucinogenic mushrooms. The Vikings of Norway, fed on fungi to stay awake and rested for their battles and conquests and South American Indians, still masse coca leaves as a natural stimulant. Chinese dynasty emperor Cheng ShenNunge describes the stimulating effect of a local plant called "machung", used by Chinese fighters and sportsmen to give more courage and courage in disputes in China, where history documents more than 2,700 a.C, (FROM ROSE, 1989)

Over the years, the use of AEAs has been significantly increasing. this growth comes from the middle of the twentieth century in the sports environment, in the so-called golden age of amateur sport. For many athletes and fans, the personal will to win an event was by itself enough to justify the use of highly dangerous substances. In one study, more than 100 high-level runners were asked whether they would consume a "magic pill" that would guarantee them an Olympic gold medal, but that the side effect was to die a year later. More than half of the athletes said they would take it even though they knew the consequences. (TODD, 1987).

There was a great deal of interest in new hormones throughout the $1930 \mathrm{~s}$ as people believed that these substances had a " power to make younger, which helped a lot in muscle growth and increased energy and libido. Kruif scientist and writer Paul in one of his 1945 books describes several studies in which he used synthetic testosterone in humans and that it somehow mysteriously gave a new life to the human body (TODD, 1987).

\subsection{Origin of Synthetic Testosterone}

In mid-1929, the German scientist Adolf Butenandt (1995) collected 1,700 (one thousand and seven hundred) liters of urine from men. From this, he managed to discriminate 15 (fifteen) milligrams of a hormone without being removed directly from the testicle, which he called androsterone, which is performed in the liver through testosterone metabolism. However, properly known testosterone, a natural male hormone and more powerful than androsterone, was only isolated in the laboratory by studying three groups of researchers funded by large multinational pharmaceutical companies (FREEDMAN, 2009).

Around 1935, Karoly Gyula David and Ernst Laqueu, subsidized by the Organon Company, dutch industry, showed a study called "On the Male Crystalline Hormone from the Testicles and Testosterone" as a result of their research on isolating testosterone.

That same year, German researchers Butenandt and Hanisch, through grants from the Berlin Schering Corporation, showed the results of their research, entitled "A method of preparing testosterone from cholesterol" (ROGERS; HARDIN, 2007).

The researchers of the pharmaceutical company Ciba, Leopold Ruizicka and Alfred Wettstein, presented their discovery in the article "The preparation of the testicular hormone testosterone (Andro-sten-3one-17-ol)". The synthesis of testosterone in the laboratory was produced and the patented such drugs in possession of the industries that subsidized its discovery.

Since then, the medicinal market for the use of synthetic testosterone and its derivatives has developed for both medicinal and static uses. Already in the 40 's, Charles Kochakian discovered the anabolic peculiarities of testosterone, that is, the ease of muscle growth made available by the use of this substance.

\subsection{General characteristics of the steroids}

Steroid hormones have lipid origin, consisting of cholesterol being synthesized only by some organs, such as gonads, ovaries and adrenal glands, located on each kidney. They are responsible for balancing the primordial functions in the body. In addition to steroids, it has insulin, glucagon and thyroid hormones, and too much. Steroids are grouped into 3 (three) basic types (VIEDO,2001).

The first is estrogen, which is the female hormone produced in the ovary and responsible for the production of female sexual characteristics. Adrenal androstenedione androgen is reverted to testosterone and estrogen when aromatized in circulation, being a relevant source of estrogen in men and postmenopausal women (DE FARIA, 2015).

The second category is androgen, a male hormone basically produced in the testicles and responsible for performing male sexual peculiarity, such as: muscle mass, strength, facial and body hair, thickening of the voice and speed of recovery of the musculature. (SOUSA, 2012)

The last category is cortisone, which is produced by both sexes and has analgesic and anti-inflammatory effect. It is the steroid hormones, natural or synthetic, related to the adrenal cortex, that interfere with or monitor the key of the body's processes, such as the metabolism of carbohydrates and proteins, the harmony of electrolytes and water, and the activities of the cardiovascular system, skeletal muscle, kidneys and other organs. (DANTAS, 2011) 
4 Silva, K.O.; Pereira, A.B.S.; Filho, P.C.B.B.; Silva, J.B.A.; Silva, J.R.F.; Santos, C.J.; Silva, N.M.; Lima e Silva, L.L.C.; Silva, M.F.G.; Silva, E.G.S.; Mota, T.J.M.S.; Santos, L.C.; Freitas, D.G.T.; Júnior, J.P.M.; Fontes, D.A.F. Steroid use and its adverse effects: a review...

Both female and male produce both hormones. Estrogens are preeminent in women, although the ovaries and adrenal gland produce smaller amounts of androgens. The same happens in the male body, in which estrogens are produced in small amounts in the testicles. (DANTAS, 2011)

\subsection{Types of Steroids}

Synthetic anabolic androgenic steroids made by pharmaceutical industries are presented in a number of ways: cream, nasal spray, suppository, skin fixation seal and sublingual, however the best known and used are oral and injectable steroids, even if everyone has to be the ability to infiltrate through the plasma membrane. (SOUSA,2012).

Oral steroids are administered in the form of tablets. Depending on the dose, the drug is often parceled during the day. Several people interested in using steroids are not available to inject the drug, so by orals, which makes them more popular among gym and bodybuilding regulars in general, even though they are more aggressive to the liver since they have a half-life, smaller than injectables. They should, however, be taken many times during the steroid cycle, causing great effort to the liver. (DANTAS, 2011)

As the liver is tasked with the extinction of any foreign body in the body, the abusive and permanent use of anabolic steroids can lead to liver dysfunction, which is usually linked to oral administration steroids, that is, 17 -alquilate steroids. Increased levels of liver enzymes such as aspartate aminotransferase, alanine aminotransferase and lactate dehydrogenase are checked in athletes using steroids (LLEWLLYN, 2011).

Injectables, on the other hand, are considered less harmful than oral ones, because they do not go through the process of alkalinization. These steroids refer to the bloodstream intramuscularly. Another benefit is that oily injectable steroids are released little by little into the circulation considering that the oil slowly spreads from the application site because of its viscosity. Then your time in circulation is the same. This mode of injection has its most soluble molecule because of the esterification of the 17hydroxil group (SANTOS, 2003).

Therefore, while oral scans should be managed on a day-to-day and day-to-day life, injectables can be administered every week or every two weeks. The disadvantage of injectables is that they demonstrate greater nephrooxidade.

AAs are clinically useful in some pathologies, including: severe burns, aplastic anemia, chronic catabolism in HIV patients, treatment of osteoporosis (e.g., raloxifene) and some neoplasms (e.g., breast) and chronic renal failure (RIBEIRO,2011)

\subsection{Indiscriminate use of EEAs}

Anabolic steroids cited for abuse include: (i) oral and injectable steroids (nandrolone decanoate), (ii) testosterone derivatives (propionate, phenylpropionate, isocaproate and decanoate), (iii) oxymetone and (iv) mesterolone (RIBEIRO,
2001).

However, what has been attracting more attention is the indiscriminate use of anabolic steroids, also part of the routine of young schoolchildren and physical activity practitioners, especially in gyms or sports centers (EVANS, 2004; PARKINSON'S; EVANS, 2006 p. 472)

Thus, considering alarming, the health risks and death of users, and in the long term the risk of death among abusive users of these substances, and is approximately four times higher than in non-users (PARSSINEN; SEPPALA, 2002).

The effects of AAs on user behavior have long been researched. Studies have linked the misuse of these drugs to sudden changes in temperament and behavioral syndromes inside and outside sports. (MIDDLEMAN et al.50, 1995 p.239)

The use of anabolic steroids against prescription, can be considered a type of abuse. Studies show that adepts of AEAs, consume in an uncontrolled manner an amount of testosterone one hundred times above the dose considered the therapeutic destination. In view, the body potential typically produces between 50 to $77 \mathrm{mg}$ of testosterone per week, the dose that these users consume per week, ranging from 350 to $700 \mathrm{mg}$ of testosterone, either intramuscularly or orally (POPE, 2000).

Another study, Ribeiro compare the use of AS in Brazil and the United States, he explains about a concern that many young people who attend academies with the scope of improving their body image, end up in turn using these substances, sometimes unaware of what they are and what they may cause (RIBEIRO PCP 2001 p.97).

\subsection{Adverse effects}

Several cardiac complications, such as heart failure, ventricular fibrillation, thrombosis, ischemic disease and acute myocardial infarction have been observed in athletes using anabolic steroids (NIEMINEN et al, 1996; SULLIVAN et al, 1998; THIBLIN et al, 2000)

Following adverse effects in men: atrophy of the testicles, low number of spermatozoa, sexual impotence, baldness, gynecomastia (may not be reversible), oliguria or dysuria and enlarged prostate. In women, male traits such as hair growth, severe voice, breast reduction, in addition to increased clitoris and delay in the menstrual cycle are clear (PEREIRA-JUNIOR et al, 2006 p. 475).

Emotional problems may occur, such as uncontrolled aggressiveness and irritability, mood swings, pathological jealousy, manic conditions, schizophrenia, delusions, distraction, forgetfulness and changes in libido, due to doses used. Abrupt discontinuation of the use of these substances can lead to abstinence depression, among other anomalies. (SANTOS, 2007; MACHADO \& RIBEIRO, 2004).

It demonstrates a study with bodybuilders, with the aid of ultrasound, that the consumption of anabolic steroids by these athletes led to an endothelium uncontrol and alteration of the lipid profile, by reducing the levels of HDL (high density lipoprotein) cholesterol, thus gradually increasing 
the risks of atherosclerosis (EBENBICHLER et al, 2001).

\section{Conclusions}

The use of Anabolic Androgenic Steroids (AAs) has been happening recklessly with increasing frequency. Its indiscriminate use, where the objective is aesthetic and performance improvements, has increased the incidences of its side effects.

Because they are used without medical supervision, outside their initial indications and, in most of the time by people seeking immediate results, these unwanted effects have often been described by their consumers. Even in the medical literature, for ethical reasons, there are no research publications related to the use of AAs for this purpose. With this, the doses that are used without scientific basis.

AAs stimulate the development of protein synthesis and are antagonists of glucocorticoids (substances that have catabolic effect and have their production increased after intense training). This effect is sufficient for a growth of muscle mass and as a consequence better aesthetic performance. In addition, they have an effect on the Central Nervous System and on the production of red blood pressures.

These drugs are medicines, so they are not seen as illicit substances in our country. To use them it is necessary that there is a medical prescription, materialized through a prescription, which must follow numerous rules for it to be accepted in pharmacies. Failure to comply with the regulations of the Ministry of Health and ANVISA may punish civilly, administratively and criminally. Where the big problem with anabolic steroids is illegal sales, counterfeits and use itself, since, most of the time, its use occurs improperly.

\section{References}

[1] BALLAL, Sudarshan H. et al. Os andrógenos potencializam os efeitos da eritropoietina no tratamento da anemia da doença renal em estágio terminal. American Journal of Kidney Diseases, v. 17, n. 1, pág. 29-33, 1991.

[2] BERNS, JS; RUDNICK, MR; COHEN, RM Um ensaio clínico controlado de eritropoietina humana recombinante e decanoato de nandrolona no tratamento da anemia em pacientes em hemodiálise crônica. Clinical nephrology, v. 37, n. 5, pág. 264-267, 1992.

[3] CELLOTTI, F.; CESI, P. Negri. Esteroides anabolizantes: uma revisão dos seus efeitos nos músculos, dos seus possíveis mecanismos de ação e da sua utilização no atletismo. The Journal of steroid biochemistry and molecular biology, v. 43, n. 5, pág. 469-477, 1992.

[4] CURRIER, JS. Como controlar as complicações metabólicas da terapia do HIV: o que fazer enquanto esperamos por respostas. O leitor da AIDS, v. 10, n. 3, pág. 162-9; discussão 171, 2000.DANTAS, J.B. Um ensaio sobre o culto ao corpo na contemporaneidade. Estud. pesqui. psicol. Rio de Janeiro, v. 11, n. 3, p. 898912, 2011.
[5] DE FARIA, Juliana Gomes et al. ESTEROIDES ANABOLIZANTES: Culto ao corpo e seus principais efeitos sobre o organismo. Rev. Conexão Eletrônica Três Lagoas, MS, v. 12, 2015.

[6] EBENBICHLER, CF et al. A vasodilatação dependente do endotélio mediada por fluxo é prejudicada em fisiculturistas do sexo masculino que tomam esteroides anabólicos androgênicos. Atherosclerosis, v. 158, n. 2, pág. 483-490, 2001.

[7] FEDER, Marta Goldman et al. Informações sobre o uso de medicamentos no esporte. Revista Brasileira de Medicina do Esporte, v. 6, n. 4, p. 125-130, 2000.

[8] FELICIO, Leandro. Os Esteroides Androgênicos Anabolizantes e a Educação Física. Salto, SP. 2010.

[9] FENICHEL, Gerald M. et al. Um ensaio randomizado de eficácia e segurança de oxandrolona no tratamento da distrofia de Duchenne. Neurology, v. 56, n. 8, pág. 10751079, 2001.

[10] FINESCHI, Vittorio et al. Abuso de esteroides anabolizantes e morte súbita cardíaca: um estudo patológico. Arquivos de patologia e medicina laboratorial, v. 125, n. 2, pág. 253-255, 2001.

[11] GRIGGS, ROBERT C. et al. Efeito da testosterona na massa muscular e na síntese de proteínas musculares. Journal of Applied Physiology, v. 66, n. 1, pág. 498-503, 1989.

[12] KASIKCIOGLU, Erdem et al. Propriedades elásticas da aorta em atletas que usam esteroides anabólicos androgênicos. Jornal internacional de cardiologia, v. 114, n. 1, pág. 132-134, 2007.

[13] MACHADO, Anderson Geraldo; RIBEIRO, Paulo César Pinho. Anabolizantes e seus riscos. Adolescência e Saúde, v. 1, n. 4, p. 20-22, 2004.

[14] OVIEDO, Eddie Alfonso Almario. As Consequências do uso indevido dos esteroides anabolizantes androgênicos nas esferas civil, penal e administrativa: Conhecer, prevenir, fiscalizar e punir. 2013.

[15] PARKINSON, Andrew B.; EVANS, Nick A. Esteroides androgênicos anabólicos: uma pesquisa com 500 usuários. Medicina e ciência em esportes e exercícios, v. 38, n. 4, pág. 644-651, 2006.

[16] PÄRSSINEN, Miia; SEPPÄLÄ, Timo. Steroid use and long-term health risks in former athletes. Sports Medicine, v. 32, n. 2, p. 83-94, 2002.

[17] PEREIRA-JUNIOR, Pedro P. et al. Disfunção autonômica cardíaca em ratos tratados cronicamente com esteroide anabolizante. Jornal europeu de fisiologia aplicada, v. 96, n. 5, pág. 487-494, 2006.

[18] POPE, Harrison G.; KOURI, Elena M.; HUDSON, James I. Efeitos de doses supra fisiológicas de testosterona no humor e na agressão em homens normais: um ensaio clínico randomizado. Arquivos de psiquiatria geral, v. 57, n. 2, pág. 133-140, 2000.

[19] RABKIN, Judith G.; WAGNER, Glenn J.; RABKIN, Richard. Um ensaio duplo-cego controlado por placebo de terapia com testosterona para homens HIV-positivos com sintomas de hipogonadismo. Arquivos de 
6 Silva, K.O.; Pereira, A.B.S.; Filho, P.C.B.B.; Silva, J.B.A.; Silva, J.R.F.; Santos, C.J.; Silva, N.M.; Lima e Silva, L.L.C.; Silva, M.F.G.; Silva, E.G.S.; Mota, T.J.M.S.; Santos, L.C.; Freitas, D.G.T.; Júnior, J.P.M.; Fontes, D.A.F. Steroid use and its adverse effects: a review...

Psiquiatria Geral, v. 57, n. 2, pág. 141-147, 2000.

[20] RIBEIRO, Paulo César Pinho. O uso indevido de substâncias: esteroides anabolizantes e energéticos. Adolesc Latinoam, v. 2, n. 2, p. 97-101, 2001.

[21] SANTOS, Azenildo Moura. O mundo anabólico: análise do uso de esteroides anabólicos nos esportes. BarueriSão Paulo, 2007.

[22] SILVA JUNIOR, Sérgio Henrique Almeida da. Morbidade hospitalar por ingestão de esteroides anabólico-androgênicos (EAA) no Brasil. Revista Brasileira de Medicina do Esporte, v. 19, p. 108-111, 2013.

[23] SOUSA, Rodrigo Vieira de. Efeitos do uso de esteroides anabolizantes. 2017.

[24] SULLIVAN, Mack Lee et al. A toxicidade cardíaca dos esteroides anabolizantes. Progresso em doenças cardiovasculares, v. 41, n. 1, pág. 1-15, 2000.

[25] WADA (World Anti-Doping Agency) World Anti-doping code. Montreal, 2006.

YESALIS, Charles E.; BAHRKE, Michael S. Doping entre atletas adolescentes. Best Practice \& Research Clinical Endocrinology \& Metabolism, v. 14, n. 1, pág. 25-35, 2000. 